\title{
Toxicity of clothianidin to common Eastern North American fireflies
}

\author{
Kirsten Ann Pearsons ${ }^{\text {Corresp., }}{ }^{1}$, Sarah Lower ${ }^{2}$, John F Tooker ${ }^{1}$ \\ ${ }^{1}$ Department of Entomology, Pennsylvania State University, University Park, Pennsylvania, United States \\ 2 Biology Department, Bucknell University, Lewisburg, Pennsylvania, United States \\ Corresponding Author: Kirsten Ann Pearsons \\ Email address: kfp5094@psu.edu
}

Background. Previous research suggests that fireflies (Coleoptera: Lampyridae) are susceptible to commonly used insecticides. In the United States, there has been a rapid and widespread adoption of neonicotinoid insecticides, predominantly used as seed coatings on large-acreage crops like corn, soy, and cotton. Neonicotinoid insecticides are persistent in soil yet mobile in water, so they have potential to contaminate firefly habitats both in and adjacent to application sites. As a result, fireflies may be at high risk of exposure to neonicotinoids, possibly jeopardizing this already at-risk group of charismatic insects.

Methods. To assess the sensitivity of fireflies to neonicotinoids, we exposed larvae of Photuris versicolor complex and Photinus pyralis to multiple levels of clothianidin-treated soil and monitored feeding behavior, protective soil chamber formation, intoxication, and mortality.

Results. Pt. versicolor and Pn. pyralis larvae exhibited long-term intoxication and mortality at concentrations above $1000 \mathrm{ng} \mathrm{g}^{-1}$ soil (1 ppm). Under sub-lethal clothianidin exposure, firefly larvae fed less and spent less time in protective soil chambers, two behavioral changes that could decrease larval survival in the wild.

Discussion. Both firefly species demonstrated sub-lethal responses in the lab to clothianidin exposure at field-realistic concentrations, although Pt. versicolor and Pn. pyralis appeared to tolerate higher clothianidin exposure relative to other soil invertebrates and beetle species. While these two firefly species, which are relatively widespread in North America, appear somewhat tolerant of neonicotinoid exposure in a laboratory setting, further work is needed to extend this conclusion to wild populations, especially in rare or declining taxa. 


\section{Toxicity of clothianidin to common Eastern North}

\section{American fireflies}

3

4 Kirsten A. Pearsons ${ }^{1}$, Sarah Lower ${ }^{2}$, John F. Tooker ${ }^{1}$

5

$6 \quad{ }^{1}$ Department of Entomology, The Pennsylvania State University, University Park, PA, USA

$7 \quad 2$ Biology Department, Bucknell University, Lewisburg, PA, USA

8

9 Corresponding Author:

10 Kirsten Pearsons ${ }^{1}$

11101 Merkle Lab, University Park, PA, 16802 USA

12 Email address: $\underline{\text { kfp5094@psu.edu }}$ 


\section{Abstract}

14 Background. Previous research suggests that fireflies (Coleoptera: Lampyridae) are susceptible

15 to commonly used insecticides. In the United States, there has been a rapid and widespread

16 adoption of neonicotinoid insecticides, predominantly used as seed coatings on large-acreage

17 crops like corn, soy, and cotton. Neonicotinoid insecticides are persistent in soil yet mobile in

18 water, so they have potential to contaminate firefly habitats both in and adjacent to application

19 sites. As a result, fireflies may be at high risk of exposure to neonicotinoids, possibly

20 jeopardizing this already at-risk group of charismatic insects.

21 Methods. To assess the sensitivity of fireflies to neonicotinoids, we exposed larvae of Photuris

22 versicolor complex and Photinus pyralis to multiple levels of clothianidin-treated soil and

23 monitored feeding behavior, protective soil chamber formation, intoxication, and mortality.

24 Results. Pt. versicolor and Pn. pyralis larvae exhibited long-term intoxication and mortality at

25 concentrations above $1000 \mathrm{ng} \mathrm{g}^{-1}$ soil (1 ppm). Under sub-lethal clothianidin exposure, firefly

26 larvae fed less and spent less time in protective soil chambers, two behavioral changes that could

27 decrease larval survival in the wild.

28 Discussion. Both firefly species demonstrated sub-lethal responses in the lab to clothianidin

29 exposure at field-realistic concentrations, although Pt. versicolor and Pn. pyralis appeared to

30 tolerate higher clothianidin exposure relative to other soil invertebrates and beetle species. While

31 these two firefly species, which are relatively widespread in North America, appear somewhat

32 tolerant of neonicotinoid exposure in a laboratory setting, further work is needed to extend this

33 conclusion to wild populations, especially in rare or declining taxa.

\section{Introduction}



services (Losey and Vaughan, 2006). Fireflies have great popular appeal and aesthetic and cultural value, but fireflies also contribute biological control of some pest species, including slugs and snails, which can be important agricultural pests (Godan, 1983; Lewis, 2016). Human activities, however, have put these services at risk by triggering global insect declines (SánchezBayo and Wyckhuys, 2019). Some charismatic groups such as fireflies (Coleoptera: Lampyridae) may be at elevated risk of at least localized extinction due to ongoing human activities such as heavy pesticide use in and around their habitats (Reed et al., 2020). (Lewis et al., 2020), there is a very poor understanding of the direct toxicity of insecticides on fireflies. The most commonly applied classes of insecticides (neonicotinoids, pyrethroids, and organophosphates) are broadly neurotoxic to most insect taxa (Sparks, 2013), so fireflies are unlikely to be an exception. Indeed, full-strength organophosphate and neonicotinoid formulations are toxic to the aquatic firefly larvae Luciola cruciata and Luciola lateralis, respectively (Tabaru et al., 1970; Lee et al., 2008). Unfortunately, there have been no studies assessing how terrestrial firefly larvae respond to residual concentrations of these insecticides in soil, a likely route of exposure. Larvae of many common firefly species in North America are soil-dwellers that intimately interact with soil as they forage for prey and form protective molting chambers (Buschman, 1984; Lewis, 2016). These larvae inhabit forested, suburban, and agricultural soils, where neonicotinoid insecticides are often applied directly, or via coatings on crop seeds, to protect against pests (Knoepp et al., 2012; Douglas and Tooker, 2015; SimonDelso et al., 2015). In these habitats, neonicotinoid concentrations in soil can range from less than $5 \mathrm{ng} \mathrm{g}^{-1}$ to over 4,000 ng g-1 (Knoepp et al., 2012; Schaafsma et al., 2015; Pearsons et al., 
59 2021), concentrations that could plausibly influence behavior and survival of firefly larvae (Lee

60 et al., 2008). Some indirect evidence suggests that firefly larvae are susceptible to neonicotinoids

61 because adult lampyrid densities have been found to be lower where neonicotinoid-coated seeds

62 were planted (Disque et al., 2019); however, to our knowledge, there have been no direct

63 evaluations of how terrestrial firefly larvae respond to neonicotinoid-treated soil.

64 To assess the direct sensitivity of fireflies to neonicotinoid insecticides, we measured

65 feeding behavior, development, and survival of larvae of two common North American firefly

66 species - Photuris versicolor species complex and Photinus pyralis (Linnaeus 1767) - exposed

67 to clothianidin-treated soil. We focused on clothianidin, one of the most widely-used seed-and

68 soil-applied neonicotinoid and the primary metabolite of another commonly applied

69 neonicotinoid, thiamethoxam (Douglas and Tooker, 2015). Generally applied to combat sucking

70 and chewing insects, clothianidin disrupts insect central nervous systems, leading to paralysis

71 and death (Simon-Delso et al., 2015). We exposed larvae to multiple field-realistic levels of

72 clothianidin-treated soil for 30 to 100 days with the expectation that they would be sensitive to

73 clothianidin at concentrations that have been detected in firefly habitats.

\section{Materials \& Methods}

\section{Chemicals}

We acquired clothianidin from Chem Service (West Chester, PA, USA; purity $\geq 98 \%$ ), and prepared stock solutions of $2 \times 10^{2}, 2 \times 10^{3}, 2 \times 10^{4}$, and $2 \times 10^{5} \mathrm{ng} \mathrm{mL}^{-1}$ clothianidin in acetone (Sigma Aldrich, St. Louis, MO, USA, ACS reagent, purity $\geq 99.5 \%$ ). Pure acetone served as a control. We stored stock solutions at $4{ }^{\circ} \mathrm{C}$ and allowed them to reach room temperature $\left(20^{\circ} \mathrm{C}\right)$ before applying them to soils for the assays. 
82

\section{Firefly Collection and Colony Care}

84 We ran toxicity assays on three separate cohorts of fireflies (Table 1): late-instar larvae from the

85 Photuris versicolor species complex (Pt. Photuris), early-instar Pt. versicolor, and early-instar

86 Photinus pyralis (Pn. pyralis). Both Pt. versicolor and Pn. pyralis are relatively large-bodied (6-

$8720 \mathrm{~mm}$ adult body length), widespread firefly species found throughout Eastern North America,

88 and their populations do not appear to be declining (Lewis, 2016). Because both species spend 1-

892 years in the soil as larvae and feed on soil invertebrates (Pt. versicolor are thought to feed on a

90 diversity of soil invertebrates whereas $P n$. pyralis larvae are considered specialists on

91 earthworms; McLean et al., 1972; Buschman, 1984; Lewis, 2016), they likely experience chronic

92 contact and oral neonicotinoid exposure in contaminated habitats.

93 Five of the late-instar Pt. versicolor were reared from eggs laid by a mated female

94 collected in late July 2019 from the Bucknell University Chillisquaque Creek Natural Area

95 (Montour Co, PA; $41^{\circ} 01^{\prime} 15^{\prime \prime} \mathrm{N}, 76^{\circ} 44^{\prime} 53^{\prime \prime} \mathrm{W}$ ), while the other 25 late-instar Pt. versicolor

96 were wild-collected in summer of 2019 from multiple locations throughout Pennsylvania: Bald

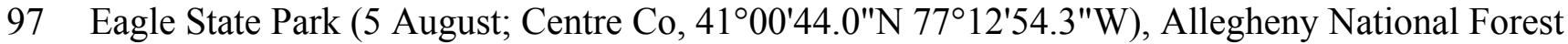

98 (24-25 June; Forest Co, 41³1'29.8"N 79¹7'33.9"W), and Bucknell University Forrest D. Brown

99 Conference Center (23-24 July; Union Co, PA; 40 57' $28^{\prime \prime} \mathrm{N}, 77^{\circ} 00^{\prime} 49^{\prime \prime} \mathrm{W}$ ). Larvae were

100 wild-collected at night by visually inspecting the ground for their faint glows. Larvae were

101 identified to genus by external morphology (McLean et al., 1972). After collection, we housed

102 individual larvae in 16-oz clear plastic deli containers $(11.5-\mathrm{cm}$ diameter $\times 8-\mathrm{cm}$ tall $)$ lined with

103 moist filter paper. Every 1-2 weeks, we provided each larva with one piece of cat food (Grain-

104 Free Real Chicken Recipe Dry Cat Food, Whole Earth Farm ${ }^{\mathrm{TM}}$, Merrick Pet Care Inc., Amarillo, 
105 TX, USA), which had been softened in DI-water for $1 \mathrm{~h}$ (McLean et al., 1972). After $24 \mathrm{~h}$, we

106 removed cat food and replaced the filter paper. Occasionally there was extensive fungal growth

107 on the cat food, which could be fatal to Pt. versicolor larvae; in these instances, we gently wiped

108 larvae with DI water and a delicate task wipe then transferred them to clean containers.

109 Early-instar Pt. versicolor and Pn. pyralis cohorts were reared from eggs laid in July

1102020 . On the evening of 10 July 2020, we collected 3 male and 2 female Pt. versicolor adults

111 and 3 mated Pt. versicolor females. Flying Pn. pyralis males were collected and identified based

112 on their characteristic "J" flash pattern (Lewis, 2016) while female Pn. pyralis were collected

113 from nearby patches of short grass and were identified based on their flash pattern and similar

114 morphology to the Pn. pyralis males (Lewis, 2016). Female Pt. versicolor were collected near

115 Pn. pyralis females and identified based on their green-shifted flash color and morphology

116 (Lewis, 2016). Additional Pn. pyralis males were collected to provision the mated Pt. versicolor

117 females. We collected Pt. versicolor and Pn. pyralis in a residential area (State College, Centre

$118 \mathrm{Co}, \mathrm{PA} ; 40^{\circ} 47^{\prime} 03^{\prime \prime} \mathrm{N}, 77^{\circ} 52^{\prime} 25^{\prime \prime} \mathrm{W}$ ) into two separate 16-oz deli container "nurseries" kept at

119 ambient room temperature $\left(20-22^{\circ} \mathrm{C}\right)$; each nursery contained a handful of moist sphagnum

120 moss on top of moist soil (2-in deep; silt loam, collected from certified organic fields at the

121 Russell E. Larson Agricultural Research Center at Rock Springs, PA, U.S.A.; 40 42' 52" N, $77^{\circ}$

$\left.12256^{\prime} 46^{\prime \prime} \mathrm{W}\right)$. Both Pn. pyralis females mated within a few minutes of collection.

123 Female Pt. versicolor and Pn. pyralis laid eggs within the following 3 days (50+Pt.

124 versicolor eggs and $100+P n$. pyralis eggs; we did not attempt more accurate counts to avoid

125 damaging eggs). Under ambient temperatures $\left(20-22{ }^{\circ} \mathrm{C}\right)$, first-instar larvae of both species began

126 to emerge three weeks after eggs were laid (5 August 2020). We kept Pt. versicolor larvae in the

127 nursery chambers for two weeks, and then, after we observed significant cannibalism among 
128 larvae, moved them into individual soil-lined 1-oz polypropylene portion containers. As with

129 larvae collected and reared from 2019, developing Pt. versicolor were fed moistened cat food

130 (Grain-Free Real Chicken Recipe Dry Cat Food, Whole Earth Farm ${ }^{\mathrm{TM}}$, Merrick Pet Care Inc.,

131 Amarillo, TX, USA) in addition to pieces of freeze-killed Lumbricus terrestris (Josh's Frogs,

132 Owosso, MI). As evidence of the hypothesis that Pn. pyralis larvae are specialist on earthworms,

133 Pn. pyralis larvae did not feed on cat food but did feed gregariously on freeze-killed L. terrestris.

134 Unlike Pt. versicolor, Pn. pyralis failed to thrive in isolation, so they were kept in the nursery

135 chamber until starting the toxicity assay.

136

137 Toxicity assay on Late-instar Photuris versicolor

138 We started the toxicity assay with late-instar Photuris versicolor on 22 June 2020. We

139 used 1-oz polypropylene portion containers containing $8 \mathrm{~g}$ of dry soil (same soil source as

140 nursery chambers) for our assay containers. To the soil in each assay container, we added $0.5 \mathrm{~mL}$

141 of the appropriate clothianidin stock solution, allowed the acetone to completely evaporate, then

142 added $2 \mathrm{~mL}$ of DI water to moisten the soil and to achieve clothianidin concentrations of $0 \mathrm{ng} \mathrm{g}^{-}$

$143{ }^{1}, 10^{1} \mathrm{ng} \mathrm{g}^{-1}$ soil, $10^{2} \mathrm{ng} \mathrm{g}^{-1}$ soil, $10^{3} \mathrm{ng} \mathrm{g}^{-1}$ soil, $10^{4} \mathrm{ng} \mathrm{g}^{-1}$ soil. We chose this concentration

144 range $\left(10^{1}-10^{4} \mathrm{ng} \mathrm{g}^{-1}\right.$ soil $)$ to encompass the range of neonicotinoid concentrations in soil that

145 have been measured in potential firefly habitats (Knoepp et al., 2012; Schaafsma et al., 2015;

146 Pearsons et al., 2021).

147 After setting up assay containers, we weighed the late-instar Pt. versicolor and randomly

148 assigned each to a particular clothianidin concentration (ensuring all larvae in each dose-set were

149 sourced from the same location). All late-instar Pt. versicolor were over 12 months old at the

150 start of the assay, and were over 10-mm long and $>50 \mathrm{mg}$ (Table 1). Each clothianidin 
151 concentration $\left(0,10^{1} \mathrm{ng} \mathrm{g}^{-1}\right.$ soil, $10^{2} \mathrm{ng} \mathrm{g}^{-1}$ soil, $10^{3} \mathrm{ng} \mathrm{g}^{-1}$ soil , $10^{4} \mathrm{ng} \mathrm{g}^{-1}$ soil $)$ was replicated

152 six times (30 late-instar Pt. versicolor larvae in total). We recorded firefly status at 1, 4, and 24

$153 \mathrm{~h}$, and every day for an additional $99 \mathrm{~d}$. Fireflies were categorized as dead (D), exhibiting a toxic

154 response $(\mathrm{T})$, or apparently healthy $(\mathrm{A})$. A larva was assumed dead if it did not respond to gentle

155 prodding with forceps. If a larva was flipped on its back and/or demonstrating repetitive

156 twitching of its legs or head, it was recorded as exhibiting a toxic response (T). Fireflies were

157 recorded as apparently healthy (A) if they exhibited a usual response to prodding from blunt

158 forceps (Fig 1A; quickly curled up on its side, often glowing). During the toxicity assay, we fed

159 larvae once a week by carefully transferring individuals out of the assay containers into clean

160 containers lined with moistened filter paper and containing a piece of moistened cat food. After

$16124 \mathrm{~h}$, we returned fireflies to the assay containers and noted if the cat food had obvious signs of

162 feeding (Fig 1B). Feeding activity for each week was measured as a simple binary $(0=$ no

163 obvious signs of feeding, 1 = obvious signs of feeding). At each status check, we noted if a

164 firefly had constructed a protective soil chamber, then carefully dismantled the chamber to check

165 larval status. Larvae often re-built soil chambers by the next day; if a larva built soil chambers on

166 multiple consecutive days (feeding days as an exception), we noted this behavior as a "period of

167 chamber formation." Assay containers were kept in a dark drawer except when doing daily

168 checks, and we misted containers with DI water as needed to keep the soil from drying out.

170 Toxicity assay on early-instar Photuris versicolor

171 The toxicity assay with early-instar Photuris versicolor was similar to the assay with late-

172 instar larvae, except we added half the amount of soil $(4 \mathrm{~g})$ and half the volume of clothianidin

173 stock solutions $(0.25 \mathrm{~mL})$ to each assay container to achieve the same clothianidin concentrations 
$174\left(0,10^{1} \mathrm{ng} \mathrm{g}^{-1}\right.$ soil, $10^{2} \mathrm{ng} \mathrm{g}^{-1}$ soil, $10^{3} \mathrm{ng} \mathrm{g}^{-1}$ soil , $10^{4} \mathrm{ng} \mathrm{g}^{-1}$ soil). All early-instar Pt. versicolor

175 were less than 3 months old and weighed between 3 and $15 \mathrm{mg}$. On 17 Sept 2020, we started

176 trials with early-instar Pt. versicolor (three replicates at each concentration, 15 larvae in total),

177 feeding them cat food once a week and recording their status at 1, 4, and $24 \mathrm{~h}$, and every day for

$17810 \mathrm{~d}$, then twice a week for an additional $90 \mathrm{~d}$. Unlike for late-instar Pt. versicolor, we fed early-

179 instars by directly placing moistened cat food in the assay containers (we removed the food $24 \mathrm{~h}$

180 later after noting if food had been damaged [1] or not [0]).

181

\section{Toxicity assay on early-instar Photinus pyralis}

183

As with the early-instar Pt. versicolor assay, the Photinus pyralis assay was run in 1-oz

184

polypropylene portion containers containing $4 \mathrm{~g}$ of soil with $0.25 \mathrm{~mL}$ doses of clothianidin stock

185 solutions (to achieve $0,10^{1} \mathrm{ng} \mathrm{g}^{-1}$ soil, $10^{2} \mathrm{ng} \mathrm{g}^{-1}$ soil, $10^{3} \mathrm{ng} \mathrm{g}^{-1}$ soil , $10^{4} \mathrm{ng} \mathrm{g}^{-1}$ soil). All early-

186 instar Pn. pyralis were less than 3 months old and weighed between 0.6 and $2.4 \mathrm{mg}$. On $17 \mathrm{Sept}$

187 2020, we started the assay on early-instar Pn. pyralis, exposing larvae in sets of five (five larvae

188 per container, three replicates at each concentration, 75 larvae in total), recorded their status at 1,

1894 , and $24 \mathrm{~h}$, and every day for $10 \mathrm{~d}$, then at least twice a week for an additional $20 \mathrm{~d}$. We

190 terminated the Pn. pyralis assay earlier than the Pt. versicolor assays due to an acarid mite

191 infestation, which rapidly increased larval mortality across all doses. During the assay, we fed

192 Pn. pyralis pieces of earthworm (L. terrestris) in the same manner that early-instar Pt. versicolor

193 were fed cat food.

194

195 Statistical Analysis

PeerJ reviewing PDF | (2021:09:65786:1:0:CHECK 20 Oct 2021) 
197 cohort, we calculated median toxic concentrations $\left(\mathrm{TC}_{50}\right)$ and median lethal concentrations

$198\left(\mathrm{LC}_{50}\right)$ at $24 \mathrm{~h}, 7 \mathrm{~d}$, and $30 \mathrm{~d}$ of exposure using probit analysis (LC_PROBIT from the "ecotox"

199 package; Robertson et al., 2017; Hlina et al., 2019); for $\mathrm{TC}_{50}$ estimates, we included both sub-

200 lethal and lethal responses, while $\mathrm{LC}_{50}$ estimates were based on mortality alone. To assess long-

201 term survivorship across clothianidin levels, we used the Kaplan-Meier method ("survival"

202 functions SURVDIFF and PAIRWISE_SURVDIFF; Therneau, 2021; Therneau and Grambsch,

203 2000). To determine how clothianidin exposure affected firefly behavior, we used non-

204 parametric Mann-Whitney U tests (WILCOX.TEST) to compare feeding frequency and soil-

205 chamber construction across clothianidin doses; we made pairwise comparisons using Wilcoxon

206 rank sum tests with continuity corrections (PAIRWISE.WILCOX.TEST). As firefly larvae

207 reduce feeding before pupation (McLean et al. 1972), we excluded the two feeding events

208 preceding pupation for feeding assessments.

209

210 Results

$21124 \mathrm{~h}, 7 \mathrm{~d}$, and $30 \mathrm{~d} \mathrm{TC} 50$ and $\mathrm{LC}_{50}$ estimates

212 Dose-response curves and estimated $\mathrm{TC}_{50}$ and $\mathrm{LC}_{50}$ indicate that Photuris versicolor and

213 Photinus pyralis were surprisingly tolerant of exposure to clothianidin (Table 2 and Fig 2-4).

214 Reliable $\mathrm{TC}_{50}$ and $\mathrm{LC}_{50}$ estimates were limited by our small sample sizes and low acute mortality

215 within the tested concentration range. Overall, $\mathrm{TC}_{50}$ values ranged from $500 \mathrm{ng} \mathrm{g}^{-1}$ to $2,000 \mathrm{ng} \mathrm{g}^{-1}$

216 while $\mathrm{LC}_{50}$ values exceeded our test limit (above 10,000 $\mathrm{ng} \mathrm{g}^{-1}$ ).

217

218 Firefly Survival 
concentrations (Fig 5). Between one and four hours after initial exposure, half of the late-instar

\section{1}

Pt. versicolor larvae and $87 \%$ of the early-instar Pn. Pyralis larvae exposed to the highest

222 clothianidin concentration $\left(10,000 \mathrm{ng} \mathrm{g}^{-1}\right)$ began to exhibit toxic responses. By $24 \mathrm{~h}$, all six late-

toxic response (Fig 2A); these larvae never recovered and died by day 84. Photuris larvae were

231 significant reduced survivorship $(P=0.07)$ while $P n$. pyralis exposed to $10,000 \mathrm{ng} \mathrm{g}^{-1}$

232 clothianidin showed significantly reduced survivorship $(P<0.0001)$ compared to controls (Fig. 233 5C).

\section{Feeding Behavior}

Clothianidin exposure significantly reduced the number of times firefly larvae fed (Fig $\mathrm{g}^{-1}$ soil fed significantly less frequently than control larvae $\left(\chi^{2}{ }_{4}=16.3, P=0.003\right)$, and early-

240 instar Pn. pyralis larvae fed significantly less at higher doses $\left(1,000 \mathrm{ng} \mathrm{g}^{-1}\right.$ and 10,000 $\left.\mathrm{ng} \mathrm{g}^{-1}\right)$

241 compared to the control or lower doses $\left(\chi^{2}{ }_{1}=12.4, P=0.0004\right)$. 
Soil-Chambers, Molting, and Pupation of Late-instar Photuris versicolor

The 14 late-instar Photuris larvae that survived as larvae through day 100 went through 1

to 5 periods of consecutive days when they regularly formed protective soil chambers (median $=$ 2 periods) and spent anywhere from 1 to 20 total days in soil chambers (median $=9 d$ ). Larvae exposed to $10,000 \mathrm{ng} \mathrm{g}^{-1}$ clothianidin never constructed soil chambers while larvae exposed to 1 ppm clothianidin spent significantly fewer days in soil chambers than larvae exposed to $10 \mathrm{ng} \mathrm{g}^{-1}$ 249 $(P=0.01 ;$ Fig 7$)$

Formation of protective soil chambers did not correspond with molting or pupation, and all recorded molting and pupation events occurred outside soil chambers, on the soil surface. Late-instar Pt. versicolor larvae only molted once or twice, irrespective of how frequently or for how long they built soil chambers (larvae that survived through 100 days; frequency: $R_{a d j}^{2}=-$ $0.09, F_{1,10}=0.10, P=0.76$; duration: $\left.R_{a d \mathrm{j}}^{2}=-0.02, F_{1,10}=0.81, P=0.39\right)$. Six of the thirty late255 256 instar Pt. versicolor larvae pupated; five of which successfully eclosed within $35 \mathrm{~d}$ of starting the assay (two controls, one at $10 \mathrm{ng} \mathrm{g}^{-1}$, two at $\left.100 \mathrm{ng} \mathrm{g}^{-1}\right)$ and one which was unsuccessful $(1,000$ ng $\left.\mathrm{g}^{-1}\right)$. The unsuccessful larva failed to shed its last-instar exoskeleton and died during the pupal stage. At $35 \mathrm{~d}$, three of the larvae exposed to the highest clothianidin concentration $\left(10,000 \mathrm{ng} \mathrm{g}^{-}\right.$ $\left.{ }^{1}\right)$ were still alive, but none of these larvae ever entered a pupal stage. Of the individuals that successfully eclosed, three were lab-reared from eggs laid in 2019 (3 out of 5) while only two were wild-collected (2 out of 25).

\section{Discussion}


clothianidin concentrations at or below $100 \mathrm{ng} \mathrm{g}^{-1}$ soil, but both firefly species exhibited 10,000 ng clothianidin $\mathrm{g}^{-1}$ soil showed a toxic response within four hours of exposure, compared over $2 \times$ and $30 \times$ the $\mathrm{TC}_{50}$ values for the earthworm Eisenia andrei and the collembolan Folsomia candida, respectively (de Lima e Silva et al., 2020). Twenty-four hour $\mathrm{LC}_{50}$ values exceeded our maximum test concentration of $10^{4} \mathrm{ng}$ clothianidin $\mathrm{g}^{-1}$ soil $(10 \mathrm{ppm})$, indicating higher tolerance to clothianidin compared to other soil-dwelling beetles (Agriotes spp. [Elateridae] and Atheta coriaria [Staphylinidae]; van Herk et al., 2007; Cloyd et al., 2009). The one other study which tested neonicotinoid toxicity to fireflies observed $13 \%$ survival of aquatic Luciola lateralis larvae after $24 \mathrm{~h}$ of exposure to $10^{5} \mathrm{ng}$ thiamethoxam $\mathrm{mL}^{-1}$ in water (Lee et al., 2008); these results suggest that fireflies as a group may be somewhat tolerant to neonicotinoid exposure, although this is likely a tenuous conclusion because it is based on just two studies that represent less than $0.2 \%$ of all described firefly species (Lewis et al., 2020). Tolerance to neonicotinoids may partly explain why populations of Pt. versicolor and Pn. pyralis do not appear to be declining as fast as rarer firefly species (Reed et al. 2020), which may be more sensitive to neonicotinoid exposure. Pt. versicolor and Pn. pyralis may tolerate clothianidin exposure due to multiple behavioral, morphological, and biochemical processes that could limit their sensitivity to clothianidin 284 (Alyokhin et al., 2008). 
287 2019), and the results of this current study provide some support for behavioral avoidance of

288 neonicotinoids by Lampyridae. Although firefly larvae could not avoid dermal exposure to the

289 treated soil in our arenas, they may have decreased oral exposure by limiting construction of

290 their soil chambers. To form soil chambers, Pt. versicolor larvae manipulate soil with their

291 mouthparts (Buschman, 1984), providing a potentially more toxic pathway for neonicotinoid

292 exposure (Decourtye and Devillers, 2010). Because neonicotinoids are repellant to other beetle

293 species (Easton and Goulson, 2013), neonicotinoid-treated soil could have repulsed firefly

294 larvae, possibly explaining reduced chamber formation above $1000 \mathrm{ng}$ clothianidin $\mathrm{g}^{-1}$ soil.

295 Alternatively, sub-lethal neonicotinoid exposure may simply decrease the ability of fireflies to

296 construct soil chambers. Choice-based avoidance studies could be used to test if avoidance or

297 direct toxicity drove the decreased time late-instar Pt. versicolor spent constructing and

298 inhabiting soil chambers at high-clothianidin concentrations.

299 In addition to behavioral avoidance, specific morphological and metabolic characteristics

300 of fireflies may protect Pt. versicolor and Pn. pyralis larvae from toxic clothianidin exposure.

301 Unlike many other soil invertebrates (e.g., earthworms and mollusks), firefly larvae have a

302 comparably protective cuticle that may act as an effective barrier against neonicotinoid uptake

303 (Decourtye and Devillers, 2010; Wang et al., 2012). And even when clothianidin is absorbed,

304 insects can resist target-site exposure by quickly detoxify and/or excrete neonicotinoids (Olson et

305 al., 2000; Alyokhin et al., 2008). Although there has been no work on neonicotinoid metabolism

306 by fireflies, Pt. versicolor and Pn. pyralis may upregulate detoxification enzymes after

307 clothianidin exposure, similar to an aquatic firefly species after exposure to benzo[a]pyrene

308 (Zhang et al., 2021). Additionally, Pt. versicolor and Pn. pyralis may be tolerant to clothianidin

309 if neonicotinoids have a low binding affinity to target sites on firefly neurons. Neonicotinoids 
310 primarily target nicotinic acetylcholine receptors (nAChRs), which regulate cation movement

311 and neuron firing in response to acetylcholine levels (Matsuda et al., 2020). Neonicotinoid

312 insecticides agonistically bind to these receptors, forcing ion channels open, leading to spasms

313 and eventual paralysis (Simon-Delso et al., 2015). As neonicotinoids have broad activity across

314 insect orders (Matsuda et al., 2020), it is unlikely that clothianidin has a low binding affinity for

315 nAChRs of Pt. versicolor and Pn. pyralis.

316 There is also the unlikely possibility that extensive neonicotinoid use has exerted

317 selection pressure on the firefly populations in central Pennsylvania to evolve resistance to

318 clothianidin. The way neonicotinoids are currently used is a perfect storm for developing

319 insecticide resistance (Tooker et al., 2017), and while most concern has focused on resistance-

320 development in herbivorous pest species, biocontrol agents and other predatory arthropods can

321 develop insecticide tolerance and resistance in response to heavy insecticide use (Bielza, 2016;

322 Mota-Sanchez and Wise, 2021). Although insecticide-resistance is thought to be rare among

323 biocontrol agents, lady beetles (Coleoptera: Coccinellidae) in particular, have been found to

324 develop resistance to a variety of broad-spectrum insecticides, including neonicotinoids (Tang et

325 al., 2015). Insecticide resistance has not been studied in many non-pest species (including

326 lampyrids), but if the selection pressure is high enough, firefly populations could evolve

327 increased tolerance or even resistance to neonicotinoid insecticides.

328 Differences among any of these potential mechanisms are likely driving differences in

329 tolerance between the two firefly species, namely, the dramatically reduced feeding response of

330 Pn. pyralis to clothianidin exposure. Although this difference could have been exacerbated by

331 mite pressure and the smaller body size of early-instar Pn. pyralis, it is possible that Pn. pyralis 
332 has higher uptake, higher active-site affinity, or lower metabolism of clothianidin as compared to

333 Pt. versicolor.

334 Despite their relative tolerance to clothianidin exposure, field-realistic neonicotinoid

335 concentrations may still pose a chronic threat to Pt. versicolor and Pn. pyralis. Although residual

336 neonicotinoid concentrations in soil are often below $100 \mathrm{ng} \mathrm{g}^{-1}$ (Schaafsma et al., 2016;

337 Radolinski et al., 2019; Pearsons et al., 2021), concentrations can regularly exceed these levels

338 after agricultural applications (as high as $594 \mathrm{ng} \mathrm{g}-123$ days after planting neonicotinoid-coated

339 seeds; Radolinski et al., 2019), after turf applications $(3 \times$ higher than in agronomic settings;

340 Armbrust and Peeler, 2002) and after soil drenches to manage hemlock wooly adelgid (over

3414,000 ng AI g ${ }^{-1}$ soil; Knoepp et al., 2012). Such high concentrations are well within the acutely

342 toxic and chronically lethal range for Pt. versicolor and Pn. pyralis larvae (Table 2).

343 Encountering such high concentrations are likely to be even more lethal under field conditions,

344 as firefly larvae that exhibited toxic responses in the laboratory would be vulnerable to predation

345 and starvation, two risks that can increase mortality from insecticides (Kunkel et al., 2001).

346 Additionally, further work is needed to assess if neonicotinoid exposure can exacerbate other

347 stressors affecting firefly populations (i.e., light pollution) or if neonicotinoids pose a significant

348 risk to firefly eggs or adults.

349 As observed with other predatory beetle species (Cycloneda sanguinea [Coccinellidae]

350 and Chauliognathus flavipes [Cantharidae]; Fernandes et al., 2016), firefly larvae exhibited

351 reduced feeding activity in response to high neonicotinoid exposure. Firefly larvae that feed less

352 frequently may have less successful eclosion rates, and those that do eclose may have lower

353 reproductive success. Additionally, the prey that fireflies encounter in neonicotinoid-

354 contaminated environments likely provide an additional neonicotinoid exposure route. Photinus 
355 larvae primarily feed on earthworms (Lewis et al., 2020), which have been found to contain

356 neonicotinoid concentrations above $200 \mathrm{ng} \mathrm{g}^{-1}$ when collected from soybean fields that were

357 planted with neonicotinoid-coated seeds (Douglas et al., 2015) and $700 \mathrm{ng} \mathrm{g}^{-1}$ when collected

358 from treated cereal fields (Pelosi et al., 2021). Firefly larvae of other species are known to feed

359 on slugs (Barker, 2004), which can also contain high doses of neonicotinoids (500 $\mathrm{ng} \mathrm{g}^{-1}$ ),

360 leading to disrupted biological control provided by carabid beetles (Douglas et al. 2015).

361 Compounded with reduced prey availability in habitats where neonicotinoids are used (Ritchie et

362 al., 2019; Tooker and Pearsons, 2021), decreased feeding activity and high risks of further

363 neonicotinoid exposure through contaminated prey may explain why adult lampyrid densities are

364 significantly lower where clothianidin has been used as a seed coating (Disque et al., 2019), even

365 if acute mortality is low. Adult fireflies may also encounter neonicotinoid residues while resting

366 on sprayed vegetation or during oviposition into soil (Pisa et al, 2021), although the risk of such

367 exposure does not appear to have been explored.

368 Despite low acute mortality, the sublethal effects of clothianidin were surprising, as some

$369 P$. versicolor larvae survived in a severely intoxicated state (not feeding, not building protective

370 soil chambers, only occasionally moving legs and/or mandibles) for over two months. A similar

371 phenomenon has been observed in European wireworms (Agriotes spp. [Coleoptera: Elateridae])

372 after exposure to clothianidin, with individuals surviving and even recovering from a severely

373 intoxicated state that can last months (van Herk et al., 2007; Vernon et al., 2007). For pests like

374 Agriotes spp., such sub-lethal effects of clothianidin exposure could still decrease crop damage

375 but may exacerbate the risk of Agriotes spp. developing neonicotinoid resistance. For predators

376 like Pt. versicolor, this long-term intoxication may limit their potential to provide biological

377 control beyond what would be expected based on population declines. 


\section{Conclusions}

381 As larvae of the two firefly species that we studied appear to be somewhat tolerant to

382 clothianidin-treated soil, neonicotinoids alone may not be significant direct factors in firefly

383 declines in North America, at least for common species. Nevertheless, firefly populations around

384 the world appear to be suffering from other stressors (e.g., habitat loss, reduced prey availability,

385 light pollution), and ecological research has demonstrated that animal populations exposed to

386 multiple stressors can suffer disproportionally more than what is suffered from a single stress

387 (Relyea and Mills 2001). Therefore, continued widespread contamination of larval firefly

388 habitats with neonicotinoids may hold potential to exacerbate the influence of other stressors on

389 declining firefly populations (Lewis et al., 2020). We encourage researchers with access to other

390 species of fireflies, particularly those with declining populations in areas where neonicotinoids

391 are commonly used, to explore their toxicological responses to insecticides.

392

393 Acknowledgements

394 We would like to thank Cheyenne McKinley and Nellie Heitzman for assistance with

395 specimen collection and rearing. Specimens were collected in Bald Eagle State Park,

396 Pennsylvania under permit SFRA-1907 to S. Lower and in Allegheny National Forest under

397 firefly monitoring permit to the Pennsylvania Firefly Festival. We would also like to thank Larry

398 Buschman for his advice on firefly collection and rearing.

399

400

References 
401

402 Alyokhin A, Baker M, Mota-Sanchez D, Dively G, Grafius E. 2008. Colorado Potato Beetle 403 resistance to insecticides. American Journal of Potato Research 85:395-413. DOI:

$404 \quad \underline{10.1007 / \mathrm{s} 12230-008-9052-0 .}$.

405 Armbrust KL, Peeler HB. 2002. Effects of formulation on the run-off of imidacloprid from turf.

$406 \quad$ Pest Management Science 58:702-706. DOI: 10.1002/ps.518.

407 Barker GM. 2004. Natural Enemies of Terrestrial Molluscs. Oxford, United Kingdom: CABI $408 \quad$ Publishing.

409 Bielza P. 2016. Insecticide Resistance in Natural Enemies. In: Horowitz AR, Ishaaya I eds.

$410 \quad$ Advances in Insect Control and Resistance Management. Switzerland: Springer

411 International Publishing, 313-329. DOI: 10.1007/978-3-319-31800-4.

412 Buschman LL. 1984. Larval biology and ecology of Photuris Fireflies (Lampyridae: Coleoptera)

413 in Northcentral Florida. Journal of the Kansas Entomological Society 57:7-16.

414 Cloyd RA, Timmons NR, Goebel JM, Kemp KE. 2009. Effect of pesticides on adult rove beetle

415 Atheta coriaria (Coleoptera: Staphylinidae) survival in growing medium. Journal of

416 Economic Entomology 102:1750-1758. DOI: $10.1603 / 029.102 .0504$.

417 Decourtye A, Devillers J. 2010. Ecotoxicity of Neonicotinoid Insecticides to Bees. In: Thany SH 418 ed. Insect Nicotinic Acetylcholine Receptors. Advances in Experimental Medicine and 419 Biology. New York, NY: Springer New York, 85-95. DOI: 10.1007/978-1-4419-6445-8 8.

420 Disque HH, Hamby KA, Dubey A, Taylor C, Dively GP. 2019. Effects of clothianidin-treated 421 seed on the arthropod community in a mid-Atlantic no-till corn agroecosystem. Pest $422 \quad$ Management Science 75:969-978. DOI: 10.1002/ps.5201. 
423 Douglas MR, Rohr JR, Tooker JF. 2015. Neonicotinoid insecticide travels through a soil food

424 chain, disrupting biological control of non-target pests and decreasing soya bean yield.

425 Journal of Applied Ecology 52:250-260. DOI: 10.1111/1365-2664.12372.

426 Douglas MR, Tooker JF. 2015. Large-scale deployment of seed treatments has driven rapid 427 increase in use of neonicotinoid insecticides and preemptive pest management in U.S. field 428 crops. Environmental Science \& Technology 49:5088-5097. DOI: 10.1021/es506141g.

Easton AH, Goulson D. 2013. The neonicotinoid insecticide imidacloprid repels pollinating flies and beetles at field-realistic concentrations. PLoS ONE 8:e54819. DOI: 10.1371/journal.pone.0054819.

432 Fernandes MES, Alves FM, Pereira RC, Aquino LA, Fernandes FL, Zanuncio JC. 2016. Lethal 433 and sublethal effects of seven insecticides on three beneficial insects in laboratory assays and field trials. Chemosphere 156:45-55. DOI: 10.1016/j.chemosphere.2016.04.115.

435 Godan D. 1983. Pest slugs and snails: biology and control. New York: Springer.

van Herk WG, Vernon RS, Clodius M, Harding C, Tolman JH. 2007. Mortality of five wireworm species (Coleoptera: Elateridae), following topical application of clothianidin and chlorpyrifos. J. Entomol. Soc. Brit. Columbia 103:55-64.

Hlina BL, Birceanu O, Robinson CS, Dhiyebi H, Wilkie MP. 2019. Changes in the sensitivity of piscicide in an invasive species. North American Journal of Fisheries Management.

441 Knoepp JD, Vose JM, Michael JL, Reynolds BC. 2012. Imidacloprid movement in soils and 442 impacts on soil microarthropods in southern Appalachian eastern hemlock stands. Journal of 443 Environmental Quality 41:469-478. DOI: 10.2134/jeq2011.0306. 
444 Korenko S, Saska P, Kysilková K, Řezáč M, Heneberg P. 2019. Prey contaminated with

445 neonicotinoids induces feeding deterrent behavior of a common farmland spider. Scientific

446 Reports 9:15895. DOI: 10.1038/s41598-019-52302-6.

447 Kunkel BA, Held DW, Potter DA. 2001. Lethal and sublethal effects of bendiocarb,

448 halofenozide, and imidacloprid on Harpalus pennsylvanicus (Coleoptera: Carabidae)

449 following different modes of exposure in turfgrass. Journal of Economic Entomology

450 94:60-67. DOI: $\underline{10.1603 / 0022-0493-94.1 .60 .}$

451 Lee K-Y, Kim Y-H, Lee J-W, Song M-K, Nam S-H. 2008. Toxicity of firefly, Luciola lateralis

452 (Coleoptera Lampyridae) to commercially registered insecticides and fertilizers. Korean

453 Journal of Applied Entomology 47:265-272.

454 Lewis S. 2016. Silent Sparks: The Wondrous World of Fireflies. Princeton, NJ: Princeton

$455 \quad$ University Press. DOI: $10.2307 /$ j.ctv7h0sxp.

456 Lewis SM, Wong CH, Owens ACS, Fallon C, Jepsen S, Thancharoen A, Wu C, De Cock R,

457 Novák M, López-Palafox T, Khoo V, Reed JM. 2020. A global perspective on firefly

458 extinction threats. BioScience 70:157-167. DOI: $\underline{10.1093 / \text { biosci/biz157. }}$

459 de Lima e Silva C, Rooij W, Verweij RA, Gestel CAM. 2020. Toxicity in neonicotinoids to

$460 \quad$ Folsomia candida and Eisenia andrei. Environmental Toxicology and Chemistry 39:548-

461 555. DOI: $10.1002 /$ etc. 4634.

462 Losey JE, Vaughan M. 2006. The economic value of ecological services provided by insects.

463 BioScience 56:311. DOI: 10.1641/0006-3568(2006)56[311:TEVOES]2.0.CO;2.

464 Matsuda K, Ihara M, Sattelle DB. 2020. Neonicotinoid insecticides: molecular targets, resistance,

465 and toxicity. Annual Review of Pharmacology and Toxicology 60:241-255. DOI:

$466 \quad$ 10.1146/annurev-pharmtox-010818-021747. 
467 McLean M, Buck J, Hanson FE. 1972. Culture and Larval Behavior of Photurid Fireflies. $468 \quad$ American Midland Naturalist 87:133. DOI: $10.2307 / 2423887$.

469 Mota-Sanchez D, Wise JC. 2021. Arthropod pesticide resistance database.

470 Olson ER, Dively GP, Nelson JO. 2000. Baseline Susceptibility to Imidacloprid and Cross

471 Resistance Patterns in Colorado Potato Beetle (Coleoptera: Chrysomelidae) Populations.

472 Journal of Economic Entomology 93:447-458. DOI: 10.1603/0022-0493-93.2.447.

473 Pearsons KA, Rowen EK, Elkin KR, Wickings K, Smith RG, Tooker JF. 2021. Small-grain cover

474 crops have limited effect on neonicotinoid contamination from seed coatings.

475 Environmental Science \& Technology 55:4679-4687. DOI: 10.1021/acs.est.0c05547.

476 Pelosi C, Bertrand C, Daniele G, Coeurdassier M, Benoit P, Nélieu S, Lafay F, Bretagnolle V,

477 Gaba S, Vulliet E, Fritsch C. 2021. Residues of currently used pesticides in soils and

478 earthworms: A silent threat? Agriculture, Ecosystems \& Environment 305:107167. DOI:

$479 \quad \underline{10.1016 / j . a g e e .2020 .107167 .}$

480 Pisa L, Goulson D, Yang E-C, Gibbons D, Sánchez-Bayo F, Mitchell E, Aebi A, van der Sluijs J,

481 MacQuarrie CJK, Giorio C, Long EY, McField M, Bijleveld van Lexmond M, Bonmatin J-

482 M. 2021. An update of the Worldwide Integrated Assessment (WIA) on systemic

483 insecticides. Part 2: impacts on organisms and ecosystems. Environmental Science and

484 Pollution Research 28:11749-11797. DOI: 10.1007/s11356-017-0341-3.

485 R Core Team. 2021. R: A Language and Environment for Statistical Computing. Vienna, Austria:

$486 \quad$ R Foundation for Statistical Computing.

487 Radolinski J, Wu J, Xia K, Hession WC, Stewart RD. 2019. Plants mediate precipitation-driven

488 transport of a neonicotinoid pesticide. Chemosphere 222:445-452. DOI:

$489 \quad$ 10.1016/j.chemosphere.2019.01.150. 
490 Reed JM, Nguyen A, Owens ACS, Lewis SM. 2020. Linking the seven forms of rarity to

491 extinction threats and risk factors: an assessment of North American fireflies. Biodiversity

492 and Conservation 29:57-75. DOI: $10.1007 / \mathrm{s} 10531-019-01869-7$.

493 Relyea RA, Mills N. 2001. Predator-induced stress makes the pesticide carbaryl more deadly to 494 gray treefrog tadpoles (Hyla versicolor). Proceedings of the National Academy of Sciences $495 \quad 98: 2491-2496$.

496 Ritchie EE, Maisonneuve F, Scroggins RP, Princz JI. 2019. Lethal and sublethal toxicity of 497 thiamethoxam and clothianidin commercial formulations to soil invertebrates in a natural 498 soil. Environmental Toxicology and Chemistry 38:2111-2120. DOI: $10.1002 /$ etc.4521.

499 Robertson JL, Jones MM, Olguin E, Alberts B. 2017. Bioassays with Arthropods. Boca Raton, $500 \quad$ FL, USA: CRC Press, Inc.

501 Sánchez-Bayo F, Wyckhuys KAG. 2019. Worldwide decline of the entomofauna: A review of its 502 drivers. Biological Conservation 232:8-27. DOI: 10.1016/j.biocon.2019.01.020.

503 Schaafsma A, Limay-Rios V, Baute T, Smith J, Xue Y. 2015. Neonicotinoid insecticide residues 504 in surface water and soil associated with commercial maize (corn) fields in southwestern 505 Ontario. PLOS ONE 10:e0118139. DOI: 10.1371/journal.pone.0118139.

506 Schaafsma A, Limay-Rios V, Xue Y, Smith J, Baute T. 2016. Field-scale examination of 507 neonicotinoid insecticide persistence in soil as a result of seed treatment use in commercial 508 maize (corn) fields in southwestern Ontario: Neonicotinoid persistence in cultivated field 509 soil. Environmental Toxicology and Chemistry 35:295-302. DOI: 10.1002/etc.3231.

510 Simon-Delso N, Amaral-Rogers V, Belzunces LP, Bonmatin JM, Chagnon M, Downs C, Furlan 511 L, Gibbons DW, Giorio C, Girolami V, Goulson D, Kreutzweiser DP, Krupke CH, Liess M, 512 Long E, McField M, Mineau P, Mitchell EAD, Morrissey CA, Noome DA, Pisa L, Settele J, 
513 Stark JD, Tapparo A, Van Dyck H, Van Praagh J, Van der Sluijs JP, Whitehorn PR,

514 Wiemers M. 2015. Systemic insecticides (neonicotinoids and fipronil): trends, uses, mode of

515 action and metabolites. Environmental Science and Pollution Research 22:5-34. DOI:

$516 \quad \underline{10.1007 / \mathrm{s} 11356-014-3470-\mathrm{y} .}$

517 Sparks TC. 2013. Insecticide discovery: An evaluation and analysis. Pesticide Biochemistry and

$518 \quad$ Physiology 107:8-17. DOI: 10.1016/j.pestbp.2013.05.012.

519 Tabaru Y, Kouketsu T, Oba M, Okafuji S. 1970. Effects of some organophosphorus insecticides

520 against the larvae of Genji firefly, Luciola cruciata and their prey, Japanese melanial snail

521 Semisulcospira bensoni. Medical Entomology and Zoology 21:178-181.

522 Tang L-D, Qiu B-L, Cuthbertson AGS, Ren S-X. 2015. Status of insecticide resistance and

523 selection for imidacloprid resistance in the ladybird beetle Propylaea japonica (Thunberg).

524 Pesticide Biochemistry and Physiology 123:87-92. DOI: 10.1016/j.pestbp.2015.03.008.

525 Therneau TM. 2021. A Package for Survival Analysis in R.

526 Therneau TM, Grambsch PM. 2000. Modeling Survival Data: Extending the Cox Model. New

$527 \quad$ York: Springer.

528 Tooker JF, Douglas MR, Krupke CH. 2017. Neonicotinoid seed treatments: Limitations and

529 compatibility with integrated pest management. Agricultural \& Environmental Letters 2:1-

530 5. DOI: $10.2134 / \mathrm{ael} 2017.08 .0026$.

531 Tooker JF, Pearsons KA. 2021. Newer characters, same story: neonicotinoid insecticides disrupt

532 food webs through direct and indirect effects. Current Opinion in Insect Science 46:50-56.

533 DOI: $\underline{10.1016 / \mathrm{j} . \text { cois.2021.02.013. }}$ 
534 Vernon RS, Van Herk W, Moffat C, Harding C. 2007. European wireworms (Agriotes spp.) in

535 North America: toxicity and repellency of novel insecticides in the laboratory and field.

$536 \quad$ IOBC/wprs Bulletin 30:35-41.

537 Wang Y, Cang T, Zhao X, Yu R, Chen L, Wu C, Wang Q. 2012. Comparative acute toxicity of

538 twenty-four insecticides to earthworm, Eisenia fetida. Ecotoxicology and Environmental

539 Safety 79:122-128. DOI: 10.1016/j.ecoenv.2011.12.016.

540 Zhang Q-L, Jiang Y-H, Dong Z-X, Li H-W, Lin L-B. 2021. Exposure to benzo[a]pyrene triggers

541 distinct patterns of microRNA transcriptional profiles in aquatic firefly Aquatica wuhana

542 (Coleoptera: Lampyridae). Journal of Hazardous Materials 401:123409. DOI:

$543 \quad$ 10.1016/j.jhazmat.2020.123409. 


\section{Table $\mathbf{1}$ (on next page)}

Summary details of the firefly larvae (three cohorts of two species) used for toxicological assays. 


\begin{tabular}{cccccc}
\hline Species & Instar group & Age (months) & Mean weight \pm SD $(\mathrm{mg})$ & \# used in assay & Source \\
\hline Pt. versicolor & late & $>12$ & $77 \pm 17$ & 30 & wild-collected \\
& early & $<3$ & $9 \pm 3$ & 15 & lab-reared \\
Pn. pyralis & early & $<3$ & $1.4 \pm 0.5$ & 75 & lab-reared \\
\hline
\end{tabular}

1 


\section{Table 2 (on next page)}

Estimated median toxic concentrations $\left(\mathrm{TC}_{50}\right)$ and lethal concentrations $\left(\mathrm{LC}_{50}\right)$ for $P$ t. versicolor and $\mathrm{Pn}$. pyralis exposure to clothianidin-contaminated soil.

95\% confidence intervals $(\mathrm{Cl})$ are based on probit analyses. Cls are not shown where data did not fit a cumulative standard normal distribution. n.r. $=$ no response in tested range. 


\begin{tabular}{|c|c|c|c|c|c|}
\hline Species & timeframe & $\begin{array}{c}\mathrm{TC}_{50} \\
\text { (ng g-1 }{ }^{-1} \text { soil) }\end{array}$ & $95 \% \mathrm{CI}$ & $\begin{array}{c}\mathrm{LC}_{50} \\
\left(\mathrm{ng} \mathrm{g}^{-1} \text { soil) }\right.\end{array}$ & $95 \% \mathrm{CI}$ \\
\hline \multirow{3}{*}{$\begin{array}{l}\text { Pt. versicolor, } \\
\text { late-instar, } \\
\text { 6 larvae / dose }\end{array}$} & $24 \mathrm{~h}$ & 1882 & $136-10,000+$ & $>10,000$ & - \\
\hline & $7 \mathrm{~d}$ & 648 & $144-3047$ & $>10,000$ & - \\
\hline & $30 \mathrm{~d}$ & 574 & 46-9895 & $>10,000$ & - \\
\hline \multirow{3}{*}{$\begin{array}{l}\text { Pt. versicolor, } \\
\text { early-instar, } \\
3 \text { larvae / dose }\end{array}$} & $24 \mathrm{~h}$ & $>10,000$ & - & n.r. & - \\
\hline & $7 \mathrm{~d}$ & 1169 & - & $>10,000$ & - \\
\hline & $30 \mathrm{~d}$ & 1169 & - & 1169 & - \\
\hline \multirow{3}{*}{$\begin{array}{l}\text { Pn. pyralis, } \\
\text { early-instar, } \\
3 \text { sets of } 5 / \text { dose }\end{array}$} & $24 \mathrm{~h}$ & 1726 & $836-3486$ & n.r. & - \\
\hline & $7 d$ & 704 & - & n.r. & - \\
\hline & $30 \mathrm{~d}$ & 316 & - & 1591 & $246-10,000+$ \\
\hline
\end{tabular}




\section{Figure 1}

Healthy Pt. versicolor larvae (A) demonstrating a typical "curl and glow" response after being prodded with blunt forceps and (B) feeding on moistened cat food. (C) An intoxicated $P t$. versicolor larva on its back, unable to right itself.

A

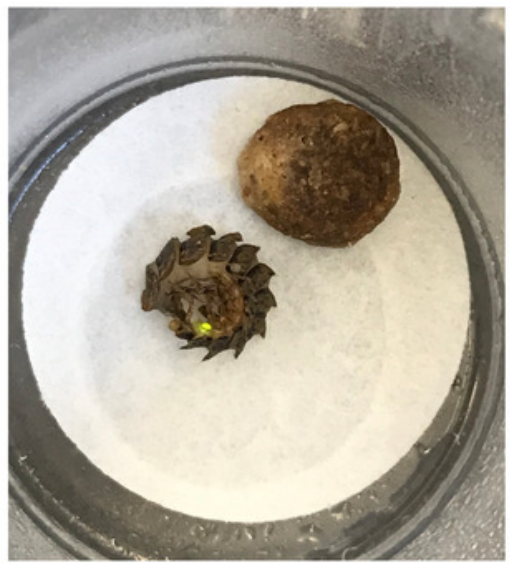

B

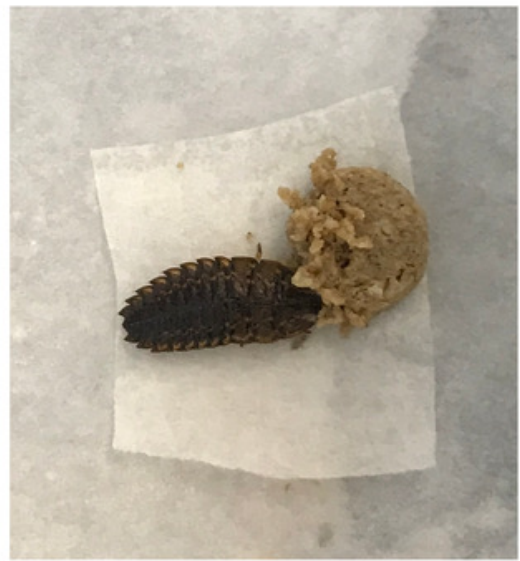

C

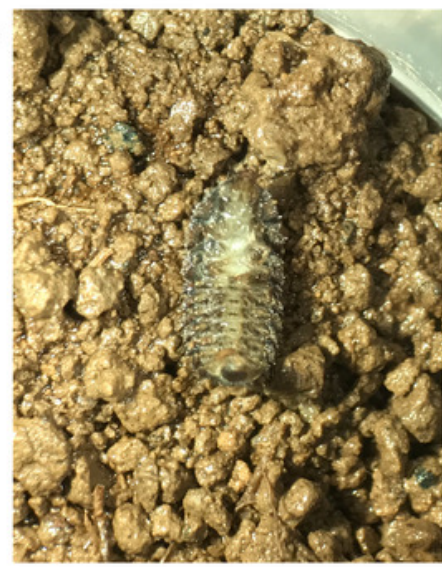


Figure 2

Dose-response curves for late-instar Pt. versicolor exposed to clothianidin-contaminated soil at $10,100,1000$, and 10,000 ng clothianidin per gram of soil ( $\mathrm{n}=6$ larvae for each concentration).

Toxic responses after (A) $24 \mathrm{~h},(B) 7 d$, and (C) $30 \mathrm{~d}$, and lethal response after (D) $24 \mathrm{~h},(\mathrm{E}) 7$ d, and (F) $30 \mathrm{~d}$. Black dots in each panel represent mean responses at each insecticide concentration; the shaded area represents the 95\% confidence interval for each curve. Blue diamonds represent the response of the control group. Dotted lines in each panel marks the $50 \%$ toxic response or mortality threshold.

A. $24 \mathrm{~h}$

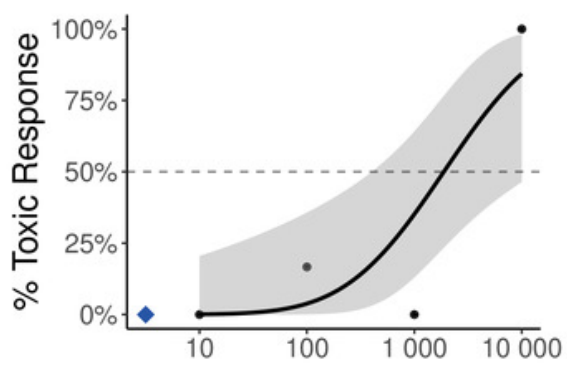

D. $24 \mathrm{~h}$

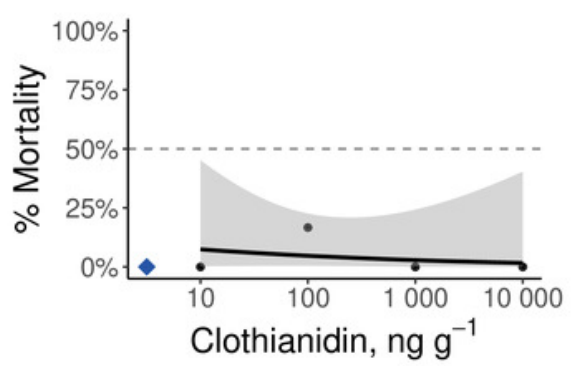

B. $7 \mathrm{~d}$

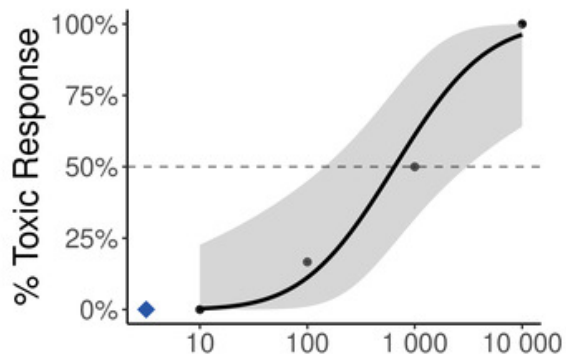

E. $7 \mathrm{~d}$

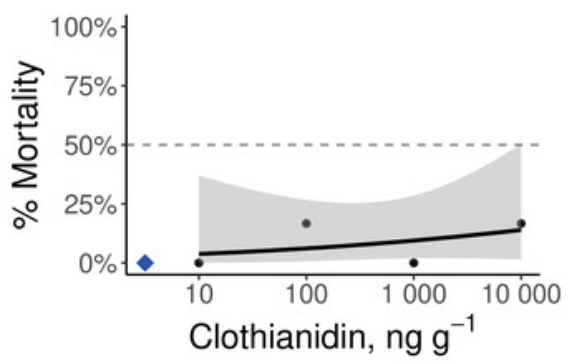

C. $30 \mathrm{~d}$

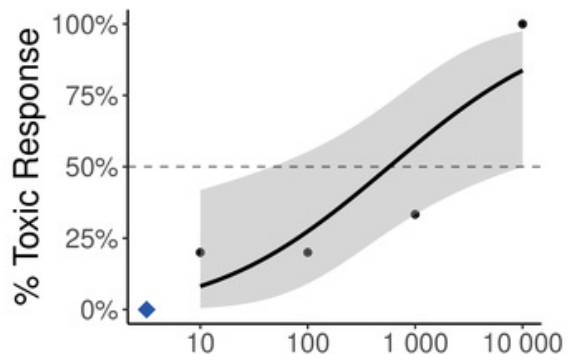

F. $30 \mathrm{~d}$

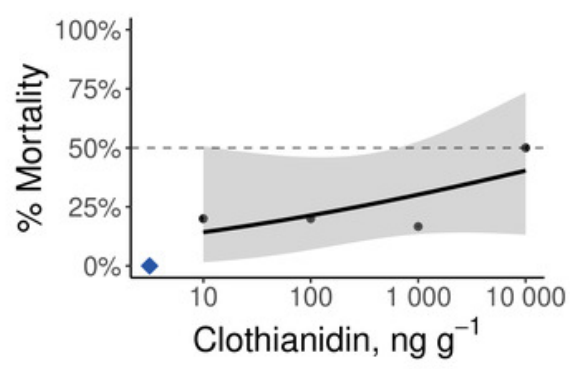




\section{Figure 3}

Dose-response curves for early-instar Pt. versicolor exposed to clothianidincontaminated soil at $10,100,1000$, and $10,000 \mathrm{ng}$ clothianidin per gram of soil $(\mathrm{n}=3$ larvae for each concentration).

Toxic responses after (A) $24 \mathrm{~h},(B) 7 \mathrm{~d}$, and (C) $30 \mathrm{~d}$, and lethal response after (D) $24 \mathrm{~h},(\mathrm{E}) 7$ d, and (F) 30 d. Black dots in each panel represent mean responses at each insecticide concentration; the shaded area represents the 95\% confidence interval for each curve. Blue diamonds represent the response of the control group. Dotted lines in each panel marks the $50 \%$ toxic response or mortality threshold.

A. $24 \mathrm{~h}$

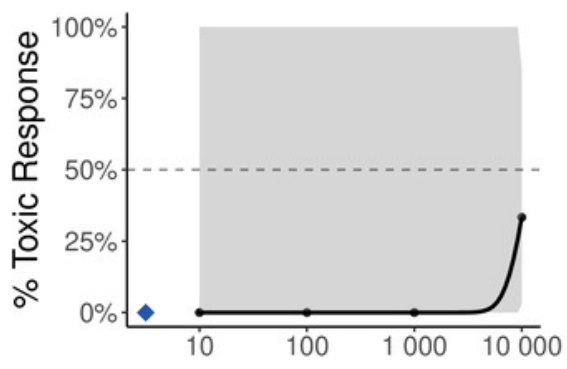

D. $24 \mathrm{~h}$

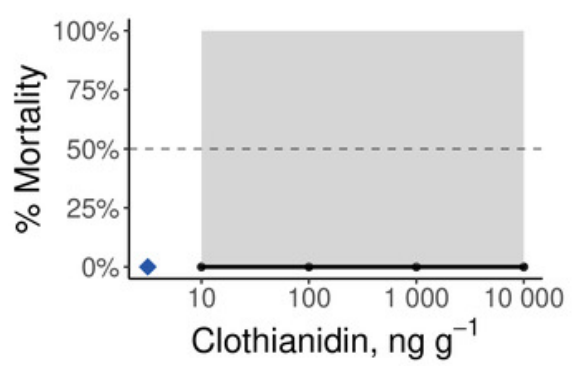

B. $7 \mathrm{~d}$

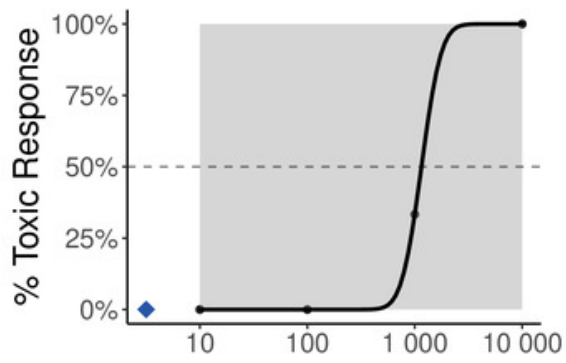

E. $7 \mathrm{~d}$

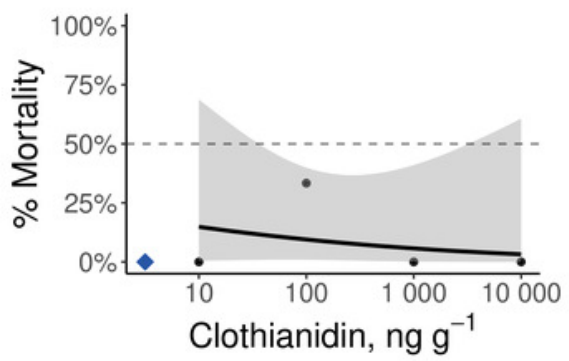

C. $30 \mathrm{~d}$

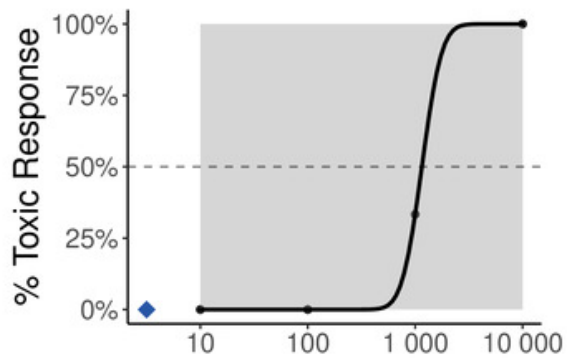

F. $30 \mathrm{~d}$

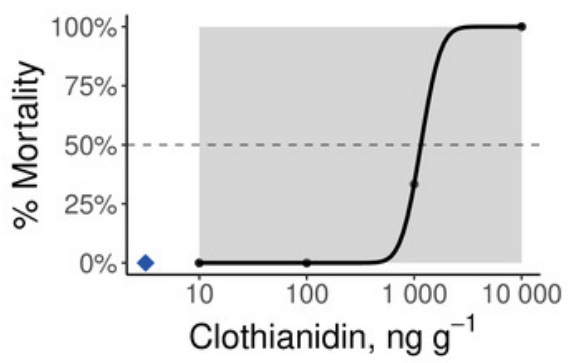


Figure 4

Dose-response curves for early-instar Pn. pyralis exposed to clothianidin-contaminated soil at $10,100,1000$, and 10,000 ng clothianidin per gram of soil ( $n=3$ sets of 5 larvae for each concentration).

Toxic responses after (A) $24 \mathrm{~h},(B) 7 d$, and (C) $30 \mathrm{~d}$, and lethal response after (D) $24 \mathrm{~h},(\mathrm{E}) 7$ d, and (F) $30 \mathrm{~d}$. Black dots in each panel represent mean responses at each insecticide concentration; the shaded area represents the 95\% confidence interval for each curve. Blue diamonds represent the response of the control group. Dotted lines in each panel marks the $50 \%$ toxic response or mortality threshold.

A. $24 \mathrm{~h}$

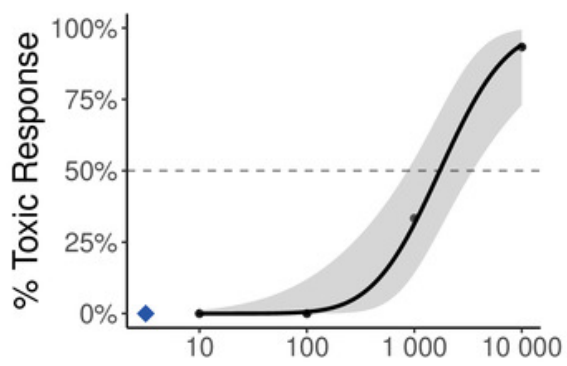

D. $24 \mathrm{~h}$

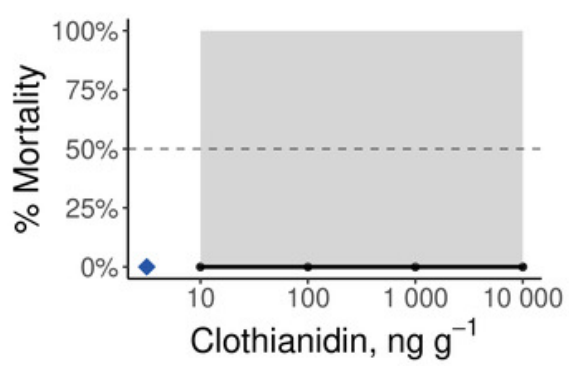

B. $7 \mathrm{~d}$



E. $7 \mathrm{~d}$

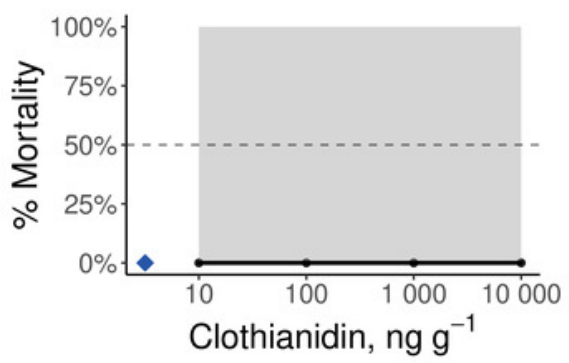

C. $30 \mathrm{~d}$

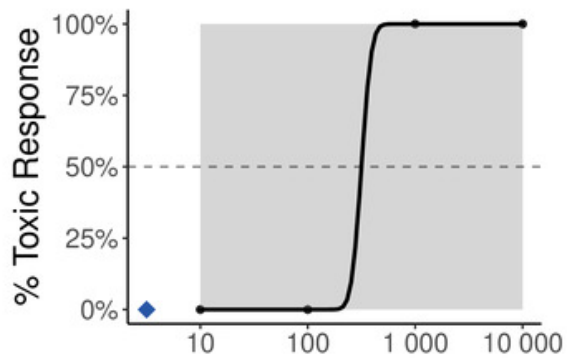

F. $30 \mathrm{~d}$

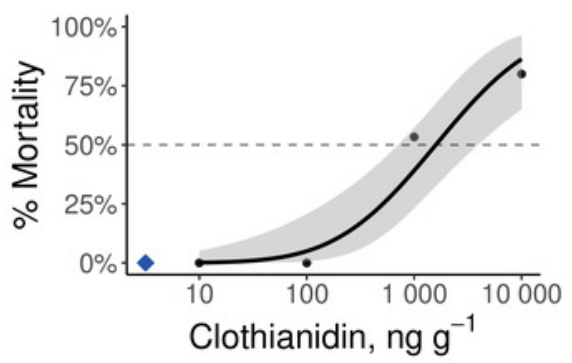




\section{Figure 5}

Survivorship curves.

A) late-instar Pt. versicolor ( $\mathrm{n}=6$ per concentration), B) early-instar Pt. versicolor ( $\mathrm{n}=3$ per concentration), and C) early-instar Pn. pyralis ( $\mathrm{n}=15$ per concentration) at different clothianidin concentrations. $P$-values next to each line indicate the significance of reduced survivorship compared to the control (with a Benjamini-Hochberg correction for multiple comparisons). $P$-values were excluded where survivorship was $100 \%$ and perfectly overlapped with control values (100 $\mathrm{ng} \mathrm{g}^{-1}$ in panel B, 10 and $100 \mathrm{ng} \mathrm{g}^{-1}$ in panel C). Survival was significantly affected by clothianidin exposure (late-instar Pt. versicolor: $\chi^{2}{ }_{4}=18, P=$ 0.001; early-instar Pt. versicolor: $\chi_{4}^{2}=12.5, P=0.01$; early-instar Pn. pyralis: $\chi^{2}{ }_{4}=58.3, P<$ $0.0001)$.

A

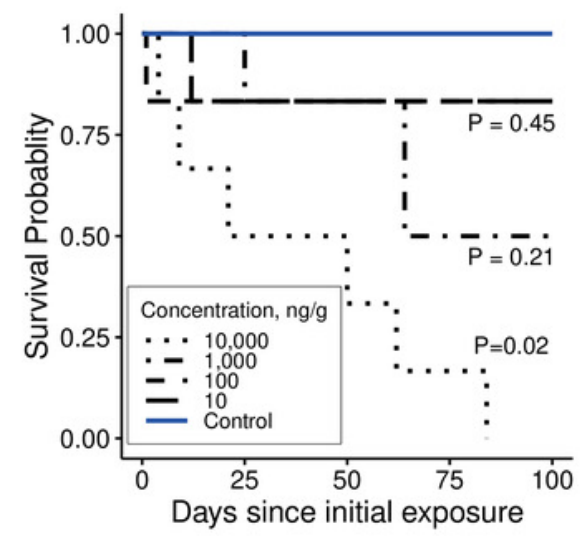

B

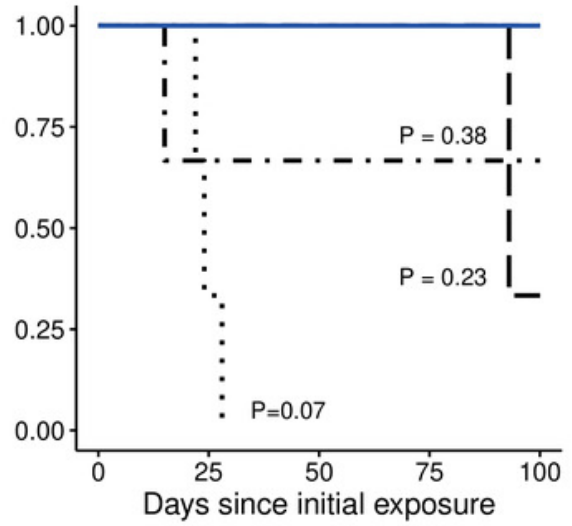

C

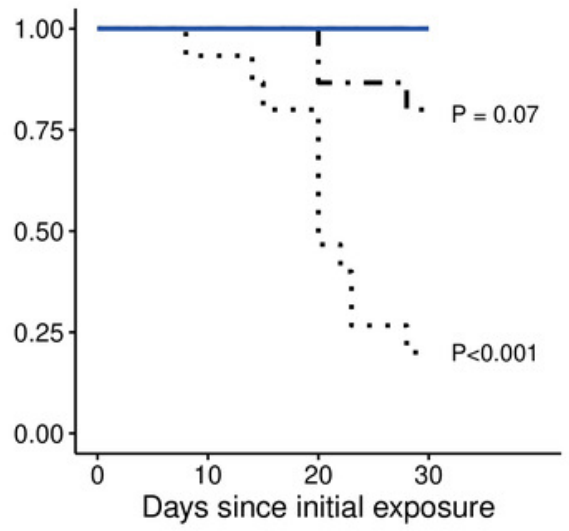




\section{Figure 6}

Percent of feeding opportunities taken by firefly larvae.

A) late-instar $P$ t. versicolor larvae $\left(\chi_{4}^{2}=15.8, P=0.003\right)$, (B) early-instar $P$ t. versicolor larvae $\left(\chi_{4}^{2}=8.2, P=0.08\right)$, and (C) early-instar $P$. pyralis larvae $\left(\chi_{1}^{2}=12.4, P=0.0004\right)$. Different letters indicate significant differences in feeding activity within each cohort at $P<0.05$ (Benjamini-Hochberg correction for multiple comparisons).
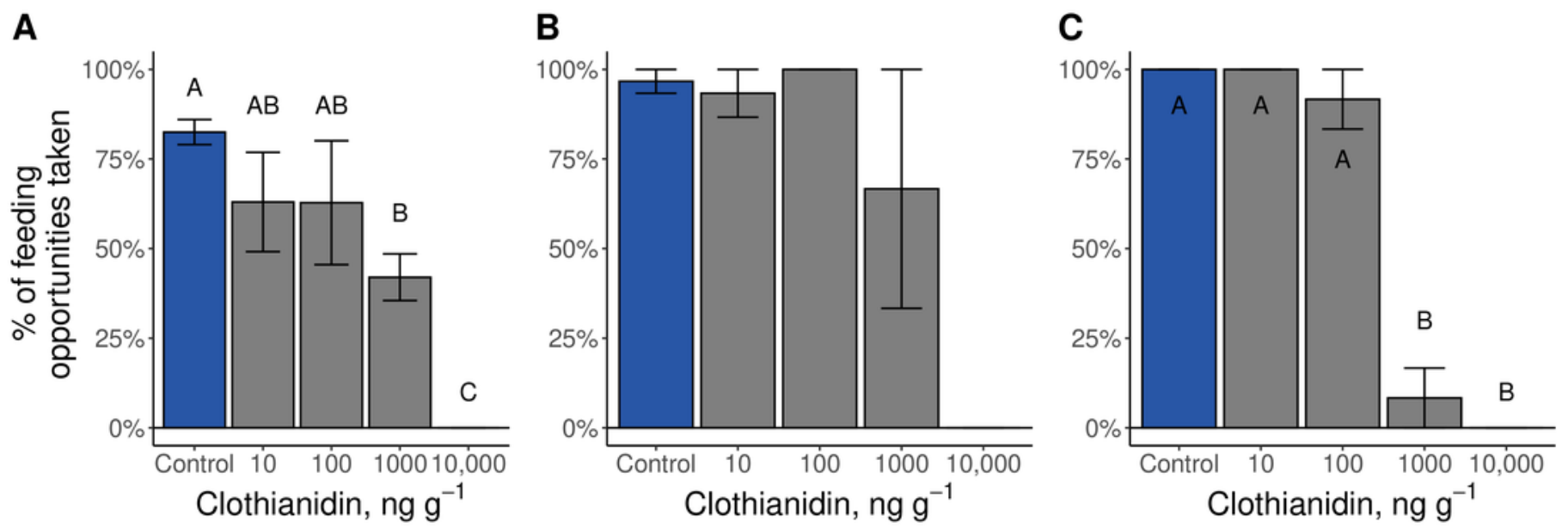
Figure 7

Amount of time that late-instar Pt. versicolor spent in soil chambers at different clothianidin-exposure levels $\left(\chi_{4}^{2}=18.4, P=0.001\right)$.

Different letters indicate significant differences at $P<0.05$ (Benjamini-Hochberg correction for multiple comparisons).

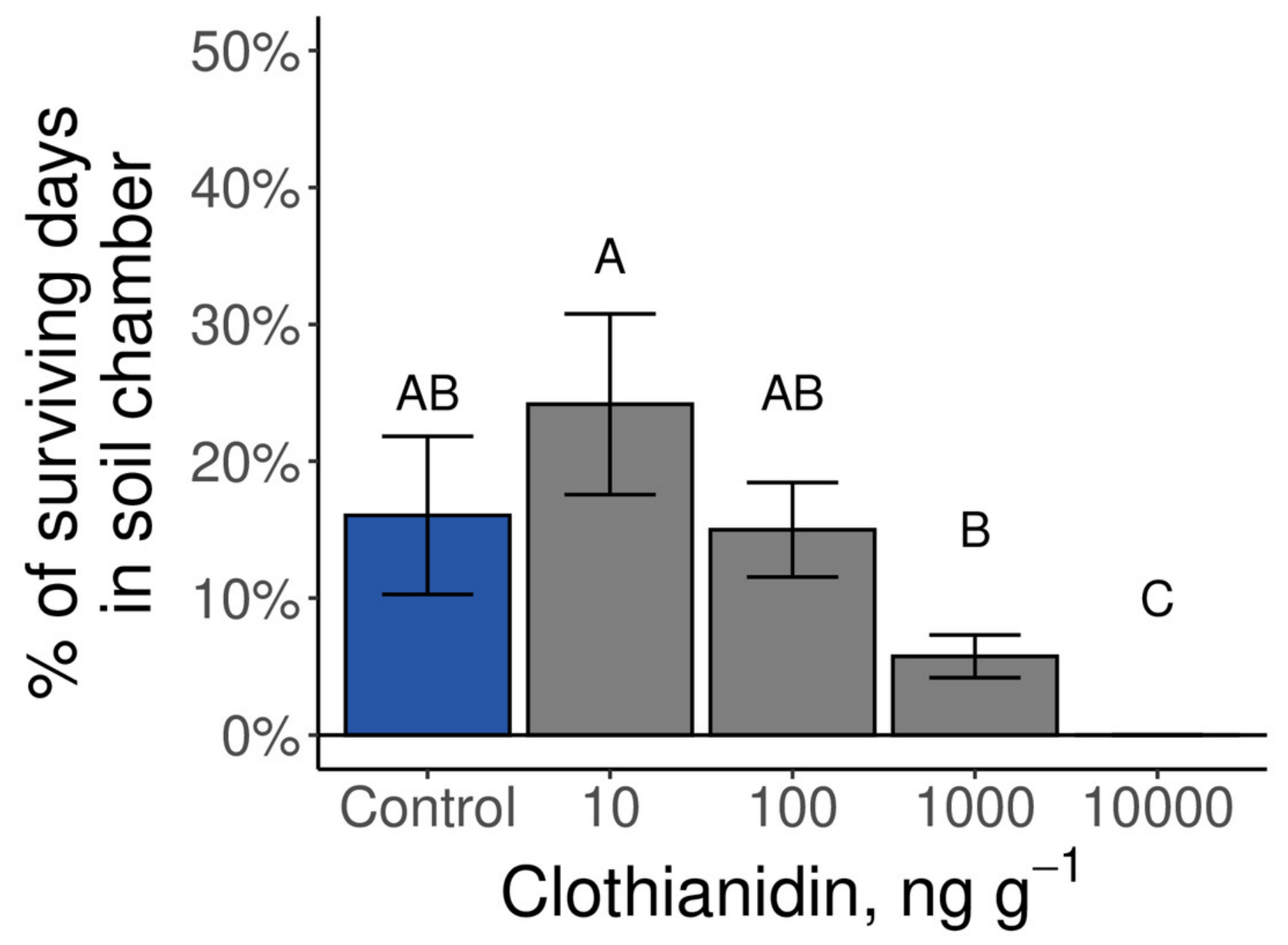

